\title{
1 Severity assessment of single dose Oxford-AstraZeneca vaccinated individuals \\ 2 infected with SARS CoV-2 in the Southeast Bangladesh
}

4 Eaftekhar Ahmed Rana ${ }^{1,6}$, Pronesh Dutta ${ }^{1,3}$, Md. Sirazul Islam* ${ }^{* 1,4}$, Tanvir Ahmad Nizami ${ }^{1,2}$,

5 Tridip Das ${ }^{1,5}$, Sharmin Chowdhury ${ }^{1,4}$, Goutam Buddha Das ${ }^{1,6}$

6 1. COVID-19 Detection Laboratory, Chattogram Veterinary and Animal Sciences University,

7 Chattogram, Bangladesh.

8 2. Department of Microbiology and Veterinary Public Health, Chattogram Veterinary and

9 Animal Sciences University, Chattogram, Bangladesh;

10 3. Department of Medicine and Surgery, Chattogram Veterinary and Animal Sciences

11 University, Chattogram, Bangladesh;

12 4. Department of Pathology and Parasitology, Chattogram Veterinary and Animal Sciences

13 University, Chattogram, Bangladesh;

14 5. Poultry Research and Training Centre, Chattogram Veterinary and Animal Sciences

15 University, Chattogram, Bangladesh;

16 6. Department of Animal Science and Nutrition, Chattogram Veterinary and Animal Sciences

17 University, Chattogram, Bangladesh; 
medRxiv preprint doi: https://doi.org/10.1101/2021.05.10.21256529; this version posted May 11, 2021. The copyright holder for this preprint

(which was not certified by peer review) is the author/funder, who has granted medRxiv a license to display the preprint in perpetuity. It is made available under a CC-BY-NC-ND 4.0 International license .

19 * Corresponding author: Md. Sirazul Islam, e-mail: sirazul@yahoo.com

20

21 Co-authors: EAR: eaftekhar@cvasu.ac.bd, PD: proneshdutta92@gmail.com, TAN:

22 tanvir.vet@gmail.com, TD: tridipdas@cvasu.ac.bd, SC: sharminchowdhury@cvasu.ac.bd, GBS:

23 gbmadhu07@yahoo.com 


\section{Abstract}

The present global endeavor to uncover the most effective vaccines against severe acute respiratory syndrome coronavirus (SARS-CoV-2) that can tremendously prevent transmission, infection and significantly reduce public health risk. COVID-19 vaccination program is underway in different parts of the world including Bangladesh but till to date there is no available health data revealed among the vaccinated peoples. We conducted a cross-sectional study from February 15 to April 15, 2021 to assess the health status of $1^{\text {st }}$ dose OxfordAstraZeneca vaccinated individuals infected with SARS CoV-2. Standard virological method, real-time reverse transcriptase-polymerase chain reaction (RT-qPCR) was performed to detect SARS-CoV-2 and the different health parameters from vaccinated individuals were collected through direct mobile phone contact using pre-structured questionnaires. A total of 6146 suspected samples were tested and 1752 were found positive for SARS-CoV-2, of them 200 individuals were identified who received $1^{\text {st }}$ dose of COVID-19 vaccine. Within the test period, majority of male (65.6\%) and female (34.4\%) carried moderate numbers of viruses which comprise between 30.01-35 cyclic threshold (ct) values. Among the vaccinated individuals, 165 (82.5\%; 95\% CI: 76.51 - 87.5) persons were not hospitalized and 177 (88.5\%; 95\% CI: 83.24 92.57) did not show any respiratory difficulties. Only a few (16) (8\%; 95\% CI: 4.64 - 12.67) of COVID-19 positive patients needed extra oxygen support and 199 (99.5\%; 95\% CI: 97.25 99.99) individuals didn't require any intensive care unit (ICU) interference. Overall, oxygen saturation was recorded around $96.8 \%$ and respiratory difficulties did not extend more than 5 days, irrespective of age and sex during the infection period. Within the vaccinated COVID-19 positive individuals 113 (56.5\%; 95\% CI: 49.33 - 63.48) and 111(55.5\%; 95\% CI: 48.32 - 62.51) persons have normal physiological taste and smell. However, we have found a larger proportion 
medRxiv preprint doi: https://doi.org/10.1101/2021.05.10.21256529; this version posted May 11, 2021. The copyright holder for this preprint

(which was not certified by peer review) is the author/funder, who has granted medRxiv a license to display the preprint in perpetuity.

It is made available under a CC-BY-NC-ND 4.0 International license .

47 of vaccinated persons (129) (64.5\%; 95\% CI: 57.44 - 71.12) carrying different comorbidity,

48 among them high blood pressure 36 (27.9\%; 95\% CI, 20.37 - 36.48) and diabetes 32 (24.8\%;

49 95\% CI: 17.63 - 33.18) were found more prevalent. Moreover, the significant finding of the

50 present study was 199 (99.5\%; 95\% CI: 97.25 - 99.99) vaccinated individuals survived with

51 good health conditions and became negative in RT-qPCR. The authors suggest that health risk

52 assessment among the COVID-19 vaccinated persons when infected with SARS-CoV-2 is

53 crucial and time demanding task for the whole world. However, the present study illustrates that

54 the administration of the 1st dose Oxford-AstraZeneca vaccine significantly reduces health risk

55 during the COVID-19 infection period.

56 Key words: Assessment, Comorbidity, COVID-19, Oxford-AstraZeneca vaccine, Health risk.

Introduction

Severe acute respiratory syndrome coronavirus (SARS-CoV-2) pandemic is envisaged as number one global public health crisis due to its high morbidity and drastic fatality rate. Since the

61 reporting of the outbreak, it has infected over 153 million of which over 3.2 million people died

62 (Worldometer 2021). Longer survival rate of virus in different environmental conditions and unprecedented speed of transmission from human-to-human can aggravate the present ongoing

64 outbreak situations (Negahdaripour, 2020). Additionally, the virus causes severe flu-like

65 symptoms with greater respiratory difficulties and reports that one infected or carrier individual

66 can easily infect others (J. Xu et al., 2020). However, the estimated reproductive number $\left(\mathrm{R}_{0}\right)$ of

67 SARS-CoV-2 is 2.2, i.e., one COVID-19 individual is able to transmit the virus to 2.2 other

68 healthy individuals ( $\mathrm{Li} \mathrm{Q}$ et al., 2020). To overcome the devastating effects of the virus on 
medRxiv preprint doi: https://doi.org/10.1101/2021.05.10.21256529; this version posted May 11, 2021. The copyright holder for this preprint

(which was not certified by peer review) is the author/funder, who has granted medRxiv a license to display the preprint in perpetuity. It is made available under a CC-BY-NC-ND 4.0 International license .

69 human health, a highly effective vaccine is a crying need. For COVID-19 prevention different vaccine platforms such as nucleic acid vaccines, recombinant protein vaccines, viral vectorbased vaccines and whole virus vaccines are targeted (Chen et al., 2020). To date, 180 different vaccine candidates are currently developing vaccines against SARS-CoV-2 (Krammer, 2020) of which 58 vaccines have been developed by different institutes and companies. Among them some vaccines are under clinical trials (Knoll and Wonodi, 2021) and few of them got permission for mass vaccination by the World Health Organization (WHO) for the successful COVAX programs co-leaded by Gavi, CEPI and WHO. Oxford-AstraZeneca chimpanzee adenovirus vectored vaccine (ChAdOx1 nCoV-19) received their license for vaccination program with a reported $90 \%$ efficacy against SARS CoV-2 after a second dose (Knoll and Wonodi, 2021). Nowadays, immunization campaign is continued in several countries including Bangladesh (DGHS 2021) irrespective of age and sex although senior citizens are experiencing a priority. The Bangladesh government started a free vaccination campaign over the country against COVID-19 using the Oxford-AstraZeneca vaccine received from the Serum Institute of India. In Chattogram division the commencement was from February 7, 2021 (The Business Standard 2021). However, the magnitude of vaccine response to the virus particle is widely varied. The significant consideration is the re-infection of previously infected or vaccinated individuals with the same virus is possible due to its high and rapid mutation rate as well as the nature of viruses (Hansen et al., 2021). However, human coronavirus does not induce lifelong

88 immunity and antibody response due to rapid fall of humoral immunity (Amanat and Florian

89 Krammer,2020). Moreover, the measurement of protective antibody titer against SARS-CoV-2

90 after vaccination is still underdeveloped. Unfortunately, after receiving the first dose

91 (approximately $5 \times 10^{10}$ viral particles) of the Oxford-AstraZeneca vaccine, a number of 
92

93

94

vaccinated people were re-infected with SARS-CoV-2. Considering the present COVID-19 pandemic crisis and vaccination status, we aimed to find out the percentages of first dose vaccinated individuals re-infected with SARS-CoV-2 and assess their health risk during the infection period.

\section{Materials and Methods}

\section{Ethical approval and authorization}

All of the samples were collected as a part of COVID-19 diagnosis that was provided by every individual with their own interest and consent. However, before the sample collection minimum discomfort was maintained in every patient and verbal permission was taken before the collection of COVID-19 vaccination history as well as health related information during the infection period. Finally, authorization from the Research and Extension director of Chattogram Veterinary and Animal Sciences University (CVASU) was taken to conduct the present study.

\section{Study area}

The present study was conveyed in the greater Chattogram division of Bangladesh which comprises 11 districts (BNP 2021/13). Geographically, it is located in the southeast part of Bangladesh and well recognized as one of the major seaports of the country (Rana et al., 2020). However, among the 11 districts, only four districts namely Khagrachhari, Rangamati, Bandarban and Chattogram were included in our study.

\section{Study Population and period}


medRxiv preprint doi: https://doi.org/10.1101/2021.05.10.21256529; this version posted May 11, 2021. The copyright holder for this preprint

(which was not certified by peer review) is the author/funder, who has granted medRxiv a license to display the preprint in perpetuity. It is made available under a CC-BY-NC-ND 4.0 International license .

113 Any individual received first dose of COVID-19 vaccine from any health care center in

114 Chattogram division irrespective of age and sex from the study area was included in the current

115 study. The study was conducted during the campaign of 1st dose vaccination which began from

116 February 15, 2021 to April 15, 2021 (2 months) before the starting of COVID-19 2nd dose

117 vaccination campaign.

\section{Sample Collection}

Nasal and oropharyngeal samples of the suspected individuals within the study area were sent to

COVID-19 detection laboratory of Chattogram Veterinary and Animal Sciences University

(CVASU) through Chattogram Medical College (CMC) and Bangladesh Institute of Tropical and

Infectious Diseases (BITID). Individual samples were collected in separate collection tubes

containing viral transport media (VTM) maintaining the WHO guidelines (WHO, 2020).

Samples were preserved into $-80^{\circ} \mathrm{C}$ temperature immediately after collection and sent to the

COVID-19 detection laboratory maintaining the proper cool chain.

\section{Molecular Diagnosis}

After receiving the suspected samples from authorities, individual samples were tested for detection of SARS-CoV-2 by RT-qPCR method. Viral RNA was extracted by using sample release reagent (SanSure Biotech, Ref. No - S1014E), following the manufacturer’s indications. Novel Coronavirus (2019-nCoV) nucleic acid diagnostic kit (PCR-Fluorescence Probing, Ref.

No- S3102E) (Sansure Biotech 2019) was used to detect the N gene (ROX channel) and ORF1ab region (FAM channel) of SARS-CoV-2 from extracted samples' RNA. To regulate the PCR

135 inhibition, human RNA targeting $P$ gene (CY 5 channel) was used as an internal control. RT- 
medRxiv preprint doi: https://doi.org/10.1101/2021.05.10.21256529; this version posted May 11, 2021. The copyright holder for this preprint

(which was not certified by peer review) is the author/funder, who has granted medRxiv a license to display the preprint in perpetuity. It is made available under a CC-BY-NC-ND 4.0 International license .

136

137 samples showed $\leq 40$ cyclic threshold (ct) value which confirmed as positive for

qPCR was performed on a QuantStudio ${ }^{\mathrm{TM}} 5$ PCR system with the version 1.5.1 for analysis. Any

COVID-19.

\section{Data Collection}

After laboratory confirmation of the SARS-CoV-2 positive cases, we traced each COVID-19 patient over the phone. Only 1st dose vaccinated COVID-19 positive individuals were included to collect data on vaccination history and health related demographic information during the infection period through a structured questionnaire. Vaccinated COVID-19 positive patients were traced until becoming free from viral infection as well as post COVID-19 complication and, COVID-19 negative test results. All data was sorted and coded in Microsoft Excel $2016^{\circledast}$ excel sheet for further summary and analysis.

\section{Statistical Analysis}

After sorting, all the data were inserted in STATA-IC $13^{\circledR}$ software to perform statistical analysis. Descriptive analysis was performed to calculate the prevalence of target outcome. The prevalence of SARS-CoV-2 was calculated considering the number of COVID-19 positive cases as the numerator divided by the total number samples as the denominator. The $95 \%$ confidence interval of the prevalence values was calculated by the modified Wald method using the Graph Pad Quickcalcs Online tool (www.graphpad.com/quickcalcs/).

\section{Results}


medRxiv preprint doi: https://doi.org/10.1101/2021.05.10.21256529; this version posted May 11, 2021. The copyright holder for this preprint

(which was not certified by peer review) is the author/funder, who has granted medRxiv a license to display the preprint in perpetuity. It is made available under a CC-BY-NC-ND 4.0 International license .

\section{Prevalence of COVID-19 vaccinated patients}

159

160

161

162

163

164

165

166

167

168

169

170

171

172

173

174

175

176

177

178

A total of 6146 suspected samples were tested by targeting SARS-CoV-2 virus within the study period, among them 1752 (28.51\%; 95\% CI: 27.38 - 29.65) samples were found positive for COVID-19. From the positive cases, we found 200 (11.42\%; 95\% CI: 9.96 - 13) individuals received the $1^{\text {st }}$ dose of Oxford-AstraZeneca vaccine. Within the vaccinated COVID-19 positive individuals 134 (67\%; 95\% CI: 60.02 - 73.47) were found male and the remaining 66 (33\%; 95\% CI: 26.53 - 39.98) were female.

In our study, we observed 165 (82.5\%; 95\% CI: 76.51-87.5), $1^{\text {st }}$ dose vaccinated COVID-19 positive patients were not admitted to hospital where according to sex, 110 (82.09\%; 95\% CI: 74.53 - 88.17) male and 55 (83.33\%; 95\% CI:72.13-91.37) female took treatment within home.

\section{Prevalence of COVID-19 vaccinated patients in different ct value categories}

All of the vaccinated SARS CoV-2 infected patients were categorized according to viral load which is based on cyclic threshold (ct) value of tested RT-qPCR (Figure 1). Among the 200 patients, 18 (9\%; 95\% CI: 5.42 - 13.85) had exhibit high viral loads irrespective of age and sex which comprise below or equal 20 ct value and occupied category 1, where 20.01 - 25 ct value, 25.01 - 30 ct value, 30.01 - 35 ct value and 35.01 - 40 ct value were in category 2, category 3, category 4 and category 5 accordingly. And most of the patients, 61 (30.5\%; 95\% CI: 24.2 37.39) were found in category 4. Within the age ranges, 40 - 49 years old individuals were found to carry high viral load during the test period. 
medRxiv preprint doi: https://doi.org/10.1101/2021.05.10.21256529; this version posted May 11, 2021. The copyright holder for this preprint

(which was not certified by peer review) is the author/funder, who has granted medRxiv a license to display the preprint in perpetuity. It is made available under a CC-BY-NC-ND 4.0 International license .

\section{Prevalence of general physiological symptoms with parameters}

180

181

182

183

184

185

186

187

188

189

190

191

192

193

194

195

196

197

198

199

The primary and well defined symptoms of the coronavirus are likely fever, coughing and sneezing. In our findings, we noticed 144 (72\%; 95\% CI: 65.23 - 78.1) individuals appear fever with variable ranges while 182 (91\%; 95\% CI: 86.15-94.58) and 89 (44.5\%; 95\% CI: 37.4951.68) COVID 19 patients didn’t have any sneezing and coughing during the infection period

(Table 1). Irrespective of ages and sex, it was observed that within the vaccinated individulas the common symptoms of sneezing and coughing were not extended more than 3 days and 7 days, respectively. However, 113 (56.5\%; 95\% CI: 49.33 - 63.48) and 111 (55.5\%; 95\% CI: 48.32 62.51) vaccinated individuals had their normal physiological taste and smell function during the infection period.

\section{Respiratory difficulties and oxygen saturation}

Shortness of breathing is one of the most significant symptoms of the COVID-19 patients. We found 177 (88.5\%; 95\% CI: 83.24 - 92.57) vaccinated patients didn’t express any breathing difficulties, of them 122 (91.04\%; 95\% CI: 84.88 - 95.29) and 55 (83.3\%; 95\% CI: 72.13 - 91.3) male and female, respectively found free from dyspnea. Moreover, in general breathing difficulties of SARS-CoV-2 infected patients were persistent around 5 days (Table 2). Interestingly, 184 (92\%; 95\% CI: 87.33-95.36) COVID-19 positive vaccinated patients didn’t require any extra oxygen support from our source. The overall oxygen saturation levels of vaccinated COVID-19 patients were found 96.8\% (95\% CI: 96.5-97.2), where it was 97\% (95\% CI: 96.5-97.4) in male and 96.5\% (95\% CI: 95.9-97.1) in females. 
medRxiv preprint doi: https://doi.org/10.1101/2021.05.10.21256529; this version posted May 11, 2021. The copyright holder for this preprint

(which was not certified by peer review) is the author/funder, who has granted medRxiv a license to display the preprint in perpetuity. It is made available under a CC-BY-NC-ND 4.0 International license .

\section{Comorbidity}

201

202

203

204

205

206

207

208

209

210

211

212

213

214

215

216

217

218

219

220

221

Within the vaccinated COVID-19 patients, a total of 129 (64.5\%; 95\% CI: 57.44 - 71.12)

individuals carried different types of comorbidity, where hypertension (36), and diabetes (32) are found more prevalent. Among the co-morbidity patients, 51 (39.5\%; 95\% CI: 31.04 - 48.52)

individuals were identified they carried more than one co-morbidity (Figure 2). Moreover, study revealed that a significant number of male 83 (61.94\%; 95\% CI: 53.16 - 70.18) suffered from different types of co-morbidity than female 46 (69.7\%; 95\% CI: 57.15 - 80.41). In our study, we found only 1 (0.5\%; 95\% CI: 0.01 - 2.75) individuals died after taking the 1st dose of OxfordAstraZeneca vaccine within the infection period.

\section{Discussion}

Assessment of the safety and efficacy of COVID-19 vaccines against the SARS-CoV-2 among the different populations is essential for an effective global pandemic response. The present study reveals the severity of single dose Oxford-AstraZeneca vaccinated people infected with SARS CoV-2 in the Southeast part of Bangladesh. The overall prevalence of positive COVID-19 individuals was $28.51 \%$ which is almost similar to $29.76 \%$ prevalence, reported in early outbreak in the same study region (Rana et al., 2020). The prevalence of 1st dose vaccinated (OxfordAstraZeneca) individuals from the positive cases were $11.42 \%$ of which $67 \%$ and $23 \%$ were found male and female, respectively. However, infection after $1^{\text {st }}$ dose vaccination was also reported among health care workers in California, USA which was $2.59 \%$ at different time intervals (Keehner et al., 2021). The reason for reinfection after vaccination might be due to the frequent mutation of SARS-CoV-2 which has less protection against certain variants like the UK 
medRxiv preprint doi: https://doi.org/10.1101/2021.05.10.21256529; this version posted May 11, 2021. The copyright holder for this preprint

(which was not certified by peer review) is the author/funder, who has granted medRxiv a license to display the preprint in perpetuity. It is made available under a CC-BY-NC-ND 4.0 International license .

222

223

224

225

226

227

228

229

230

231

232

233

234

235

236

237

238

239

240

241

242

243

variant (B.1.1.7), South African variant (B.1.351), and Brazilan variant (P1/P2) which were recently detected in Bangladesh (icddr,b, 2021). Since the Oxford-AstraZeneca vaccine was designed by targeting the spike protein gene but frequent mutation of this region may alter the immunological response and fail to give protection. The newly emerged variants are said to have greater transmissibility and continuously harbour new genetic changes, which may impact on clinical manifestation and vaccine effectiveness (icddr,b, 2021). Mahdi et al, 2021 also reported two-dose regimen of ChAdOx1-nCoV19 did not show protection against mild-moderate Covid19 caused by B.1.351 variant. However, experiments reveal that a single standard dose of Oxford AstraZeneca vaccine provided around 76\% protection against symptomatic patients with COVID-19 (Wise, 2021).

Among the vaccinated positive individuals $82.5 \%$ did not need any hospital care and they received nursing staying at home. This finding supports Iacobucci, 2021 who also reported 80\% reduction of hospital admission after $1^{\text {st }}$ dose vaccination with Oxford-AstraZeneca. The reason behind lower hospital admission rates might be due to the protection and efficacy given by the vaccine against severe clinical symptoms (Knoll and Wonodi, 2021). Body immunity developed in response to vaccines which also works to reduce the severity of infections and subside the systemic clinical manifestation thus ultimately prevent mortality (Ramasamy et al., 2020).

The present findings reported 28\%, 44.5\% and 91\% vaccinated individuals did not show any symptoms of fever, coughing and sneezing, respectively during the infection period. The duration and severity of all symptoms were also found low. Furthermore, 56.5\% and 55.5\% individuals had no changes in their normal taste and smell sensation. The reason for milder symptoms of COVID-19 positive vaccinated individuals might be due to the quick immune 
medRxiv preprint doi: https://doi.org/10.1101/2021.05.10.21256529; this version posted May 11, 2021. The copyright holder for this preprint

(which was not certified by peer review) is the author/funder, who has granted medRxiv a license to display the preprint in perpetuity. It is made available under a CC-BY-NC-ND 4.0 International license .

244

245

246

247

248

249

250

251

252

253

254

255

256

257

258

259

260

261

262

263

264

265

266

response generated by ChAdOx1-nCoV19 maintaining a certain antibody titer that inhibit viral replication and reducing viral loads (Hung et al., 2021; Wise, 2021).

Breathing difficulties and low oxygen saturation are commonly noticed in severe COVID-19 patients. However, in our study 88.5\% 1st dose vaccinated individuals did not show any sign of dyspnoea and their average oxygen saturation level was found normal (96.8\%). This is because SARS-CoV-2 infection is generally mild in the majority of individuals. However, it is well defined the Oxford-AstraZeneca vaccine is developed based on SARS-CoV-2 spike protein gene which replicates inside the host cell after immunization and produces significant T-cell responses against it which prevents SARS-CoV-2 spike protein binding to angiotensin-converting enzyme 2 (ACE-2) receptor of lungs and also capable to neutralize the virus inside the host body (Ramasamy et al., 2020; Bertoletti et al, 2021). Very few vaccinated individuals develop respiratory difficulties which might be due to presence of comorbidities, secondary bacterial infection and an initial defect in antiviral host defense mechanisms (Netea et al., 2020). Recent emergence of the UK, B.1.1.7 (also called 501Y.V1) includes eight amino acid changes within the spike. One of these, N501Y (Asn 501 Tyr), increases the affinity of spike to binding its cellular target ACE-2 receptor and causes severe lung damage during the replication process. And thus underlying causes significantly reduce oxygen consumption as well as blood oxygen saturation level and probably this is the main trigger for breathing difficulties in COVID-19 positive individuals (Altmann et al., 2021; Bertoletti et al, 2021).

Presence of comorbidities are linked to severity of COVID-19 and substantially associated with significant morbidity and mortality (Ejaz et al., 2020). Although 17.5 percent vaccinated yet infected patients were admitted to the hospital, no serious health risk was observed despite presence of co-morbidities in $64.5 \%$ individuals. Among different kinds of comorbidities 
medRxiv preprint doi: https://doi.org/10.1101/2021.05.10.21256529; this version posted May 11, 2021. The copyright holder for this preprint

(which was not certified by peer review) is the author/funder, who has granted medRxiv a license to display the preprint in perpetuity. It is made available under a CC-BY-NC-ND 4.0 International license .

267 hypertension was found to be highest (27.9\%) followed by diabetes (24.8\%). SARS-CoV-2

268 utilizes ACE-2 receptors expressed at the surface of the host cells to access inside the cell.

269 Certain comorbidities are associated with a potent ACE-2 receptor expression and higher release

270 of pro-protein convertase that enhances the viral entry into the host cells (Ejaz et al., 2020).

271 However, the presence of comorbidities especially diabetes increases susceptibility of SARS

272 CoV-2 infection (Erener, 2020) and significantly reduces the body immunity function. Moreover,

273 it also enhances the acute cytokine storm, pulmonary dysfunction and hypercoagulation of SARS

274 CoV-2 infected patients (Erener, 2020). About 199 (99.5\%) individuals were found alive upto

275 negative COVID-19 test results, while only one individual with a history of kidney

276 transplantation and presence of multiple comorbidities died.

277 Minimum adverse events or deaths in ChAdOx1 nCoV-19 single dose vaccine recipients were

278 also reported by Knoll and Wonodi, 2021. Oxford AstraZeneca vaccines are found effective in

279 reducing COVID-19 infections and protecting against severe disease in adults (Iacobucci, 2021).

280 However, only vaccinated individuals were considered for this study where a comparison study

281 between vaccinated and non-vaccinated individuals is also important for an effective vaccine

282 efficacy study. It is also better to sequence the viruses that infect the vaccinated individuals and

283 help to identify the strain and nature as well as molecular dynamics of SARS CoV-2. The study

284 was conducted in a certain geographical location of Bangladesh. However, elaborate studies

285 including large number vaccinated individuals in all the divisions of Bangladesh are

286 recommended for future studies that make clear understanding about vaccine efficacy against

287 COVID-19.

288 
medRxiv preprint doi: https://doi.org/10.1101/2021.05.10.21256529; this version posted May 11, 2021. The copyright holder for this preprint

(which was not certified by peer review) is the author/funder, who has granted medRxiv a license to display the preprint in perpetuity. It is made available under a CC-BY-NC-ND 4.0 International license .

\section{Conclusion}

290

291

292

293

294

295

296

297

298

299

300

301

302

303

304

305

306

307

308

309

The present investigation evidently focused the SARS-CoV-2 onfall even though reception of $1^{\text {st }}$ dose Oxford-AstraZeneca COVID-19 vaccine. However, the hearty finding is $82.5 \%$ single dose vaccinated COVID-19 patients did not require any hospital care and 88.5\% individuals did not face any respiratory difficulties. Despite the presence of different comorbidities in the vaccinated patients, only $8 \%$ of the study population required extra oxygen support and negligible (0.5\%) number of patients admitted into ICU. The study concludes that vaccination with a single dose Oxford AstraZeneca vaccine significantly reduced severity and mortality of COVID-19 patients in southeast Bangladesh. Finally, we propose the studies of SARS-CoV-2 infection after vaccination should be integrated into the development of highly effective and durable immune responses producing vaccines that curb the COVID-19 pandemic.

\section{Conflict of Interest}

The authors have no conflict of interest to declare.

\section{Author's Contribution}

EAR planned, designed the study and prepared the initial draft of the manuscript. EAR, PD, MSI, TAN, and TD executed laboratory tasks, data entry and manuscript preparation. PD and TD analysed and summarised the data. SC and GBD supervised the study and revised the final manuscript. All authors read and approved the final manuscript. 
medRxiv preprint doi: https://doi.org/10.1101/2021.05.10.21256529; this version posted May 11, 2021. The copyright holder for this preprint

(which was not certified by peer review) is the author/funder, who has granted medRxiv a license to display the preprint in perpetuity. It is made available under a CC-BY-NC-ND 4.0 International license.

\section{Acknowledgement}

311 The authors acknowledge CMC and BITID for providing samples from different regions of the

312 Chattogram division. The authors also acknowledge Fahad Hossain Palash and Md. Jahid Hasan

313 for collecting patients’ data. The laboratory reagent facilities were supported by the Directorate

314 General of Health Services, People’s Republic of Bangladesh. The authors sincerely

315 acknowledge the Director, Poultry Research and Training Centre (PRTC), CVASU for

316 laboratory logistic support. The study was funded by the Director of Research \&

317 Extension,CVASU.

\section{Reference}

1. Krammer, F., 2020. SARS-CoV-2 vaccines in development. Nature, 586(7830), pp.516527.

2. Negahdaripour, M. (2020). The battle against COVID-19: Where do we stand now?Iranian Journal of Medical Sciences, 45(2), 81-82.

3. Xu, J., Zhao, S., Teng, T., Abdalla, A. E., Zhu, W., Xie, L., ... Guo, X. (2020). Systematic comparison of two animal to human transmitted human

4. coronaviruses: SARS-CoV-2 and SARS-CoV. Viruses, 12(2),E244

5. Li Q, Guan X, Wu P, Wang X, Zhou L, Tong Y, et al. Early transmission dynamics in Wuhan, China, of novel coronavirus-infected pneumonia. N Engl J Med. 2020. https://doi.org/10.1056/ NEJMoa2001316.

6. Knoll, M.D. and Wonodi, C., 2021. Oxford-AstraZeneca COVID-19 vaccine efficacy. The Lancet, 397(10269), pp.72-74. 

pipeline: an overview. Current tropical medicine reports, pp.1-4.

8. Amanat, F. and Krammer, F., 2020. SARS-CoV-2 vaccines: status report. Immunity, 52(4), pp.583-589.

Nizami, T.A., Chakraborty, P. and Siddiki, A.Z., 2020. Molecular detection and

10. World Health Organization. (2020) Laboratory Testing for Coronavirus Disease 2019

12. Bangladesh National Portal (BNP), 2021. List of Districts-Chattogram Division.

Available from: http:/www.chittagongdiv.gov.bd/site/page/98079ea0-2144-11e7-8f57286ed488c766/At\%20a\%20glance. Retrieved on 05-04-2021

13. The Business Standard., 2021 https://www.tbsnews.net/coronavirus-chronicle/covid-19bangladesh/deputy-education-minister-nowfel-receives-first-covid. Retrieved on 05-042021

14. Sansure Biotech 2019. http://eng.sansure.com.cn/index.php? g=\&m=article\&a=index\&id=81. Retrieved on 05-04-2021 hospital admission by $80 \%$ in over 80s, data suggest." (2021).

16. Bernal, J. L., Andrews, N., Gower, C., Stowe, J., Robertson, C., Tessier, E., ... \& Ramsay, M. (2021). Early effectiveness of COVID-19 vaccination with BNT162b2 
mRNA vaccine and ChAdOx1 adenovirus vector vaccine on symptomatic disease, hospitalisations and mortality in older adults in England. MedRxiv.

17. Ramasamy, M. N., Minassian, A. M., Ewer, K. J., Flaxman, A. L., Folegatti, P. M., Owens, D. R., ... \& Demissie, T. (2020). Safety and immunogenicity of ChAdOx1 nCoV19 vaccine administered in a prime-boost regimen in young and old adults (COV002): a single-blind, randomised, controlled, phase 2/3 trial. The Lancet, 396(10267), 1979-1993. 19 vaccine AstraZeneca. Jan 28, 2021. https://www.gov. uk/government/publications/regulatory-approval-of-covid-19-vaccine-astrazeneca (accessed Apr 18, 2021). vaccine followed by a 12-week booster. The Lancet, 397(10277), 854-855.

20. Zimmer C, Corum J, Wee S. Coronavirus vaccine tracker. New York Times. 2020.https://www.nytimes.com/interactive/2020/science/coronavirus- vaccine-

21. Knoll, M. D., \& Wonodi, C. (2021). Oxford-AstraZeneca COVID-19 vaccine efficacy. The Lancet, 397(10269), 72-74. dosing interval. Abeles, S.R. and Torriani, F.J., 2021. SARS-CoV-2 infection after vaccination in health care workers in California. New England Journal of Medicine. 

casts doubt on efficacy against variant.

25. Madhi, S. A., Baillie, V., Cutland, C. L., Voysey, M., Koen, A. L., Fairlie, L., ... \& Izu, A. (2021). Safety and efficacy of the ChAdOx1 nCoV-19 (AZD1222) Covid-19 vaccine of concern. Science, 371(6534), 1103-1104. Crevel, R., van de Veerdonk, F. L., \& Bonten, M. (2020). Trained immunity: a tool for reducing susceptibility to and the severity of SARS-CoV-2 infection. Cell.

28. Bertoletti, A., Tan, A. T., \& Le Bert, N. (2021). The T-cell response to SARS-CoV-2: kinetic and quantitative aspects and the case for their protective role. Oxford Open Immunology, 2(1), iqab006.

29. Ejaz, H., Alsrhani, A., Zafar, A., Javed, H., Junaid, K., Abdalla, A. E., ... \& Younas, S. (2020). COVID-19 and comorbidities: Deleterious impact on infected patients. Journal of Infection and Public Health.

30. Erener, S., 2020. Diabetes, infection risk and COVID-19. Molecular Metabolism, p.101044.

31. Hansen, C.H., Michlmayr, D., Gubbels, S.M., Mølbak, K. and Ethelberg, S., 2021. 
Table 1: Prevalence of different physiological conditions of vaccinated COVID-19 individuals during SARS CoV-2 infection period

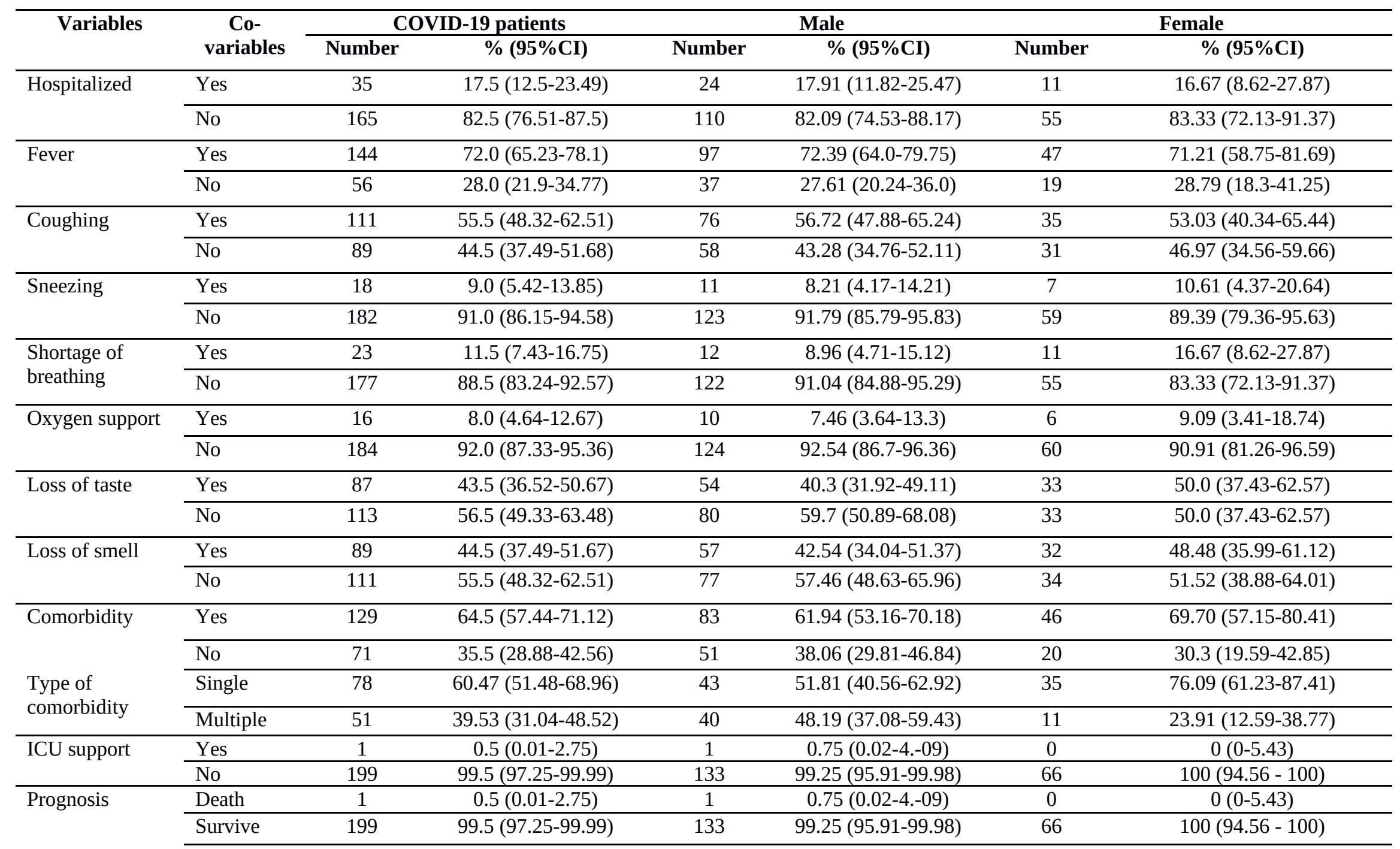


Table 2: Different physiological parameters of vaccinated COVID-19 patients during infection period.

\begin{tabular}{|c|c|c|c|c|c|c|}
\hline \multirow[t]{2}{*}{ Variables } & \multicolumn{2}{|c|}{ COVID-19 patients } & \multicolumn{2}{|l|}{ Male } & \multicolumn{2}{|c|}{ Female } \\
\hline & Mean \pm SE (95\% CI) & Min - Max & Mean \pm SE (95\% CI) & Min - Max & Mean \pm SE (95\% CI) & Min- Max \\
\hline $\begin{array}{l}\text { COVID-19 positive result } \\
\text { after onset of vaccination } \\
\text { (days) }\end{array}$ & $32 \pm 1.2(29.7-34.3)$ & $1-61$ & $32 \pm 1.4(29.1-34.8)$ & $1-61$ & $32 \pm 2(28.1-35.9)$ & $3-57$ \\
\hline Duration of fever (days) & $3.9 \pm 0.2(3.5-4.4)$ & $1-15$ & $3.9 \pm 0.3(3.4-4.5)$ & $1-10$ & $3.9 \pm 0.4(3.1-4.6)$ & $1-15$ \\
\hline $\begin{array}{l}\text { Body temperature } \\
\left({ }^{\circ} \text { Fahrenheit) }\right.\end{array}$ & $100.9 \pm 0.1(100.7-101.2)$ & $99-104$ & $100.9 \pm 0.1(100.6-101.2)$ & $99-104$ & $101 \pm 0.2(100.7-101.3)$ & $99-104$ \\
\hline $\begin{array}{l}\text { Duration of coughing } \\
\text { (days) }\end{array}$ & $6.4 \pm 0.4(5.5-7.2)$ & $1-25$ & $6.5 \pm 0.6(5.4-7.6)$ & $1-25$ & $6.1 \pm 0.7(4.7-7.5)$ & $2-21$ \\
\hline $\begin{array}{l}\text { Duration of sneezing } \\
\text { (days) }\end{array}$ & $2.9 \pm 0.5(1.8-4)$ & $1-8$ & $2.5 \pm 0.6(1.2-3.9)$ & $1-8$ & $3.7 \pm 1(1.1-6.2)$ & $2-8$ \\
\hline $\begin{array}{l}\text { Duration of shortness of } \\
\text { breathing (days) }\end{array}$ & $4.8 \pm 0.7(3.4-6.3)$ & $1-12$ & $5 \pm 1.1(2.5-7.5)$ & $3-12$ & $4.6 \pm 0.9(2.4-6.8)$ & $1-8$ \\
\hline $\begin{array}{l}\text { Oxygen saturation level } \\
\text { (\%) }\end{array}$ & $96.8 \pm 0.2(96.5-97.2)$ & $90-99$ & $97 \pm 0.2(96.5-97.4)$ & $90-99$ & $96.5 \pm 0.3(95.9-97.1)$ & $90-99$ \\
\hline
\end{tabular}



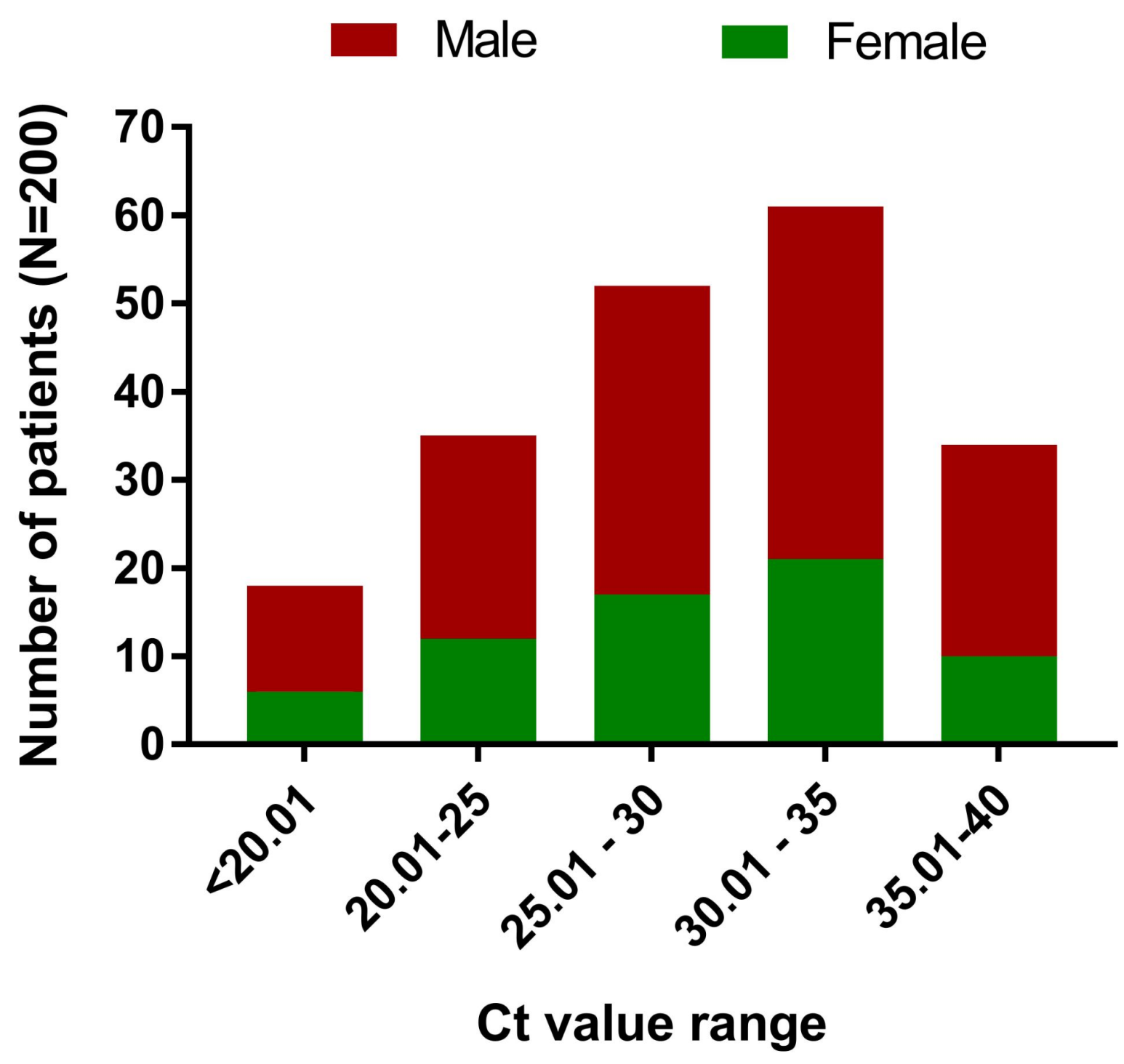

409 Figure 1: Category of SARS CoV-2 infected vaccinated patients based on viral load using cyclic

410 threshold (ct) value of RT-qPCR. Where category 1: $\leq 20$ (ct); category 2: 20.01-25 (ct); category

411 3: 25.01-30 (ct); category 4: 30.01-35 (ct) and category 5: 35.01-40 (ct). 
medRxiv preprint doi: https://doi.org/10.1101/2021.05.10.21256529; this version posted May 11, 2021. The copyright holder for this preprint (which was not certified by peer review) is the author/funder, who has granted medRxiv a license to display the preprint in perpetuity.

It is made available under a CC-BY-NC-ND 4.0 International license .

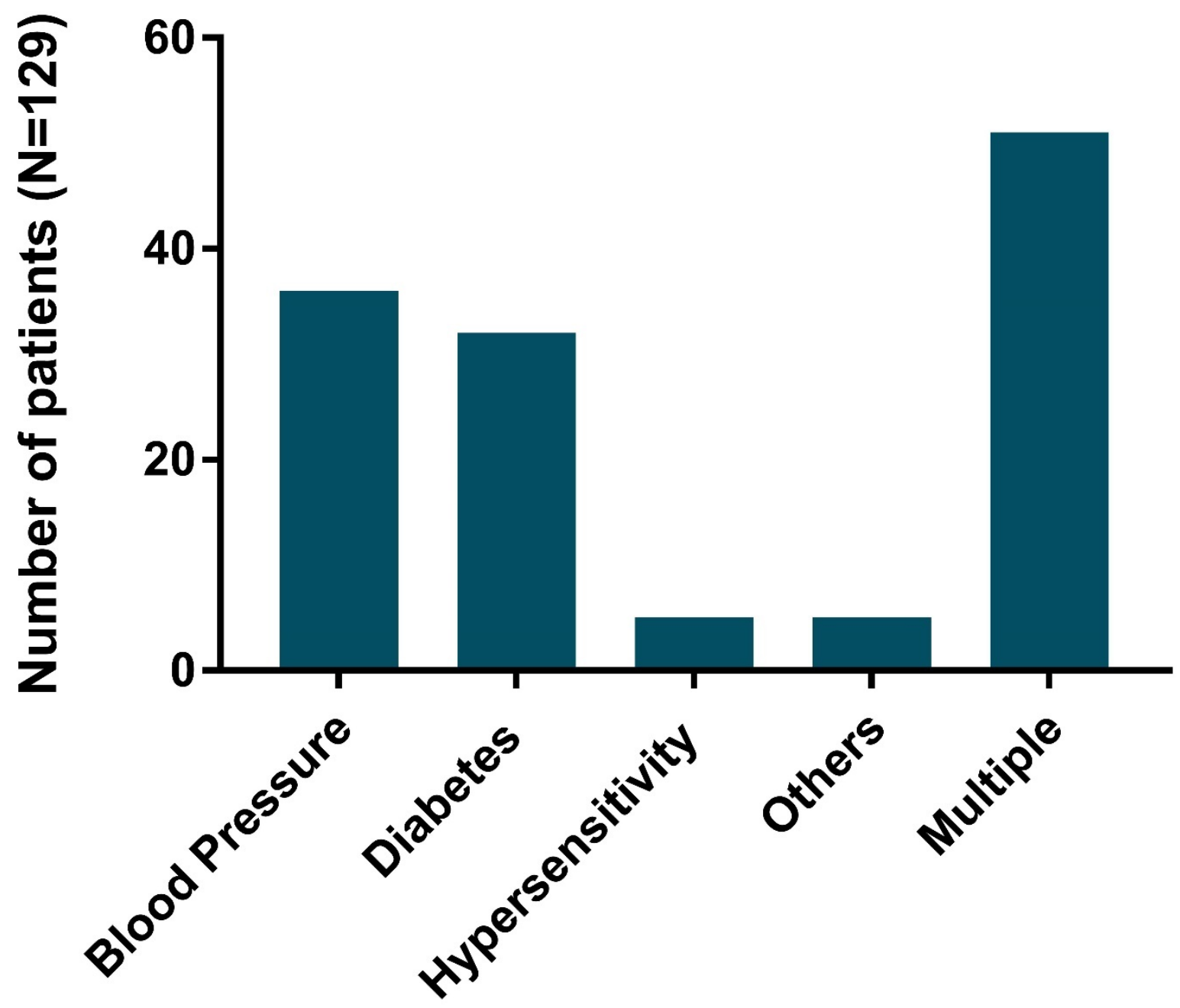

\section{Types of comorbidity}

415 Figure 2: Prevalence of different comorbidity retaining COVID-19 patients infected with SARS

416 CoV-2 after vaccination. Here, comorbidity type others include cardiac disorder, kidney disease 417 and liver disease. 